\title{
Some aspects of the role of viruses in cancer
}

\author{
C. W. PotTer \\ Ph.D., M.R.C.Path. \\ Department of Virology, University of Sheffield Medical School, Sheffield, Yorkshire
}

\begin{abstract}
Summary
The cells of tumours induced by many oncogenic DNA viruses, or cells transformed in vitro, contain virus-specific $\mathrm{T}$ and transplantation antigens; these have been described for SV40 virus, polyoma virus and adenoviruses. The investigation of viruses as causes of malignant disease in man has sought to establish whether tumour cells possess these virusspecific proteins; however, to date and with the limitations of present techniques, this enquiry has not demonstrated the above viruses as causal of human cancer. More recent studies with herpesvirus type 2 (HSV-2) have shown this virus to transform animal and human cells in culture, and induce cancer in experimental animals: for these reasons, many researchers have suggested that this agent may be an agent of some forms of cancer, in particular carcinoma of the cervix. The possible association of HSV-2 with human malignant disease is discussed.
\end{abstract}

SINCE the first description of viruses as a cause of cancer in chickens (Ellerman and Bang, 1908), a profusion of other viruses have been shown to cause cancer in animals. The virus-induced malignancies include leukaemias, lymphomas, sarcomas and carcinomas, and the animals affected include mice, hamsters, rabbits, chickens and monkeys (Rapp and Reed, 1977). There is no objective reason why man should be excluded from the list of species affected by cancers caused by viruses; however, the ethics which prevent experimentation and the lack of inbred lines available in other species, and which have proved crucial in many experiments, has prohibited the direct experimental approach used in animal studies. This has required investigators to use indirect methods of investigation, which can provide circumstantial evidence of association but cannot afford proof that viruses cause cancer. The oncogenic viruses of animals include both RNA and DNA viruses classified in a number of different groups (Green, 1977). Researchers of human cancer have suggested a variety of viruses as possibly implicated in human cancer (Todaro and Huebner, 1972; Klein, 1972); however, the strongest case at the present time is for DNA viruses, and the methods used for these investigations are animal studies, the transformation of animal and human cells grown in tissue culture, the detection of virus or $\overrightarrow{0}$ virus-specific nucleic acid in cancer cells and the presence of viral antibodies in patients with malignant disease (Rapp and Reed, 1977).

\section{Oncogenic DNA viruses}

Table 1 lists examples of oncogenic DNA viruses in 3 groups; some of the viruses are associated with naturally occurring cancers, whilst others only produce tumours when inoculated into experimental animals. Thus, the papovaviruses include rabbit papilloma virus which induces benign papillomata in cottontail rabbits and which in other rabbit species can develop to a malignant carcinoma; polyoma and SV40 viruses which are widespread in mice and monkeys respectively, and induce tumours when inoculated into newborn mice or hamsters: and the papovaviruses of man which are associate with progressive multifocal leucoencephalopath逭 Eight human, 6 simian, one avian and one bovine serotypes are among the adenoviruses which induce lymphosarcomas when inoculated into newborn hamsters (Trentin, Van Hoosier and Samper, 1968; Merkov and Slifkin, 1973). The herpesviruses include 2 viruses associated with naturally occurring malignant diseases of leopard frogs and fowls (Lucké, 1938; Churchill and Briggs, 1967), and at least 2 monkey herpesviruses which can induce lymphomas when inoculated into monkeys of a different species. In addition, the herpesviruses include 2 infective agents of man that have been implicated in human malignant disease; these are the Epstein-Barr virus associated with Burkitt's lymphoma (Zur Hausen, 1975), and herpesvirus type 2 which has been associated with carcinoma of the cervix (Nahmias et al., 1970). The list of viruses shown in Table 1 is not complete; several other DNA viruses could be added, and further virus-tumour associations have been reported but the results require confirmation.

\section{Oncogenicity of adenovirus and SV40 virus}

(a) Tumour induction in experimental animals

Inoculation of newborn hamsters with SV40 virus or human adenovirus types 12,18 and 31 and, $\stackrel{\oplus}{?}$ to a lesser extent, with types $3,4,7,14$ and 21 , 7 induces tumours at the site of inoculation; the 
The role of viruses in cancer

TABle 1. Oncogenic DNA viruses

\begin{tabular}{|c|c|c|c|}
\hline Virus group & Virus (natural host) & Species affected & Tumour type \\
\hline \multirow{4}{*}{ Papovaviruses } & (Papilloma (rabbit) & cottontail & carcinoma \\
\hline & Polyoma (mouse) & $\begin{array}{l}\text { mouse } \\
\text { hamster }\end{array}$ & $\begin{array}{l}\text { fibrosarcoma } \\
\text { leukaemia } \\
\text { parotid tumour }\end{array}$ \\
\hline & SV40 (monkey) & $\begin{array}{l}\text { mouse } \\
\text { hamster }\end{array}$ & fibrosarcoma \\
\hline & Papovavirus (man) & hamsters & $\begin{array}{l}\text { fibrosarcoma } \\
\text { (progressive multifocal } \\
\text { lencoencephalopathy of man) }\end{array}$ \\
\hline \multirow[b]{2}{*}{ Adenoviruses } & 8 serotypes (man & & \\
\hline & $\left\{\begin{array}{l}6 \text { serotypes (monkey) } \\
1 \text { serotype (bovine) } \\
1 \text { serotype (avian) }\end{array}\right.$ & hamster, mouse & lymphosarcoma \\
\hline \multirow{4}{*}{ Herpesviruses } & $\left\{\begin{array}{l}\text { Lucké virus (frog) } \\
\text { Marek's disease (fowls) } \\
\text { H. Samiri (monkey) }\end{array}\right.$ & $\begin{array}{l}\text { leopard frogs } \\
\text { fowls } \\
\text { marmosets } \\
\text { monkeys }\end{array}$ & $\begin{array}{l}\text { adenocarcinoma } \\
\text { lymphoma } \\
\text { lymphoma }\end{array}$ \\
\hline & H. Ateles (spider monkey) & monkeys & lymphoma \\
\hline & Epstein-Barr virus (man) & $\operatorname{man}$ & $\begin{array}{l}\text { infectious mononucleosis } \\
\text { (Burkitt's lymphoma) }\end{array}$ \\
\hline & Herpesvirus I and II (man) & $\begin{array}{l}\text { mouse } \\
\text { hamster }\end{array}$ & $\left\{\begin{array}{l}\text { adenocarcinoma/ } \\
\text { fibrosarcoma }\end{array}\right.$ \\
\hline
\end{tabular}

TABLE 2. Transplantation immunity to adenovirus 12-induced tumour cells

\begin{tabular}{|c|c|c|c|c|c|c|}
\hline & \multirow[b]{2}{*}{ Immunizing antigen } & \multicolumn{4}{|c|}{ Incidence of tumours at day:* } & \multirow{2}{*}{$\begin{array}{l}\text { Total } \\
(\%)\end{array}$} \\
\hline & & 7 & 14 & 21 & 35 & \\
\hline \multirow{2}{*}{ Experiment 1} & $\int \begin{array}{l}X \text {-irradiated Ad } 12 \\
\text { tumour cells }(\times 3)\end{array}$ & $0 / 15$ & $0 / 15$ & $1 / 15$ & $2 / 15$ & $13 \cdot 3 \dagger$ \\
\hline & $\begin{array}{l}\text { X-irradiated normal } \\
\text { cells }(\times 3)\end{array}$ & $0 / 15$ & $6 / 15$ & $14 / 15$ & $15 / 15$ & 100 \\
\hline \multirow{3}{*}{ Experiment 2} & $\begin{array}{l}\text { Cell-free extract } \\
\text { Ad } 12 \text { tumour cells }(\times 3)\end{array}$ & $0 / 20$ & $1 / 20$ & $2 / 20$ & $3 / 20$ & $15+$ \\
\hline & $\begin{array}{l}\text { Cell-free extract } \ddagger \\
\text { S4V0 tumour cells }(\times 3)\end{array}$ & $0 / 20$ & $11 / 20$ & $20 / 20$ & - & 100 \\
\hline & $\begin{array}{l}\text { Cell-free extract } \\
\text { normal cells }(\times 3)\end{array}$ & $0 / 20$ & $16 / 20$ & $18 / 20$ & $20 / 20$ & 100 \\
\hline Experiment 3 & $\begin{array}{l}\text { Adenovirus } 12 \\
\text { SV40 } \\
\text { NIL }\end{array}$ & $\begin{array}{l}0 / 15 \\
0 / 15 \\
0 / 15\end{array}$ & $\begin{array}{l}0 / 15 \\
4 / 15 \\
7 / 15\end{array}$ & $\begin{array}{r}2 / 15 \\
12 / 15 \\
13 / 15\end{array}$ & $\begin{array}{r}4 / 15 \\
14 / 15 \\
13 / 15\end{array}$ & $\begin{array}{l}26 \cdot 7 \dagger \\
93 \cdot 3 \\
86 \cdot 7\end{array}$ \\
\hline
\end{tabular}

* Immunized hamsters inoculated with $5 \times 10^{5}$ viable adenovirus 12 tumour cells.

$\dagger P=<0.01$.

‡ This extract induced immunity to SV40-induced tumour cells.

tumours appear several months later, are encapsulated and enlarge rapidly, do not metastasize and can be transplanted to newborn or adult hamsters. Histological examination shows the tumour cells to be fibrosarcoma or anaplastic small cell tumours of questionable histogenesis (I. Carr, personal communication). The surface of all tumours induced by SV40 virus or adenovirus 12, including tumours of different animal species, possess a common virus-specific transplantation antigen (TSTA) not present on normal cells. These antigens can be demonstrated by transplantation immunity tests; thus, hamsters, immunized with homologous, irradiated tumour cells or extracts of tumour cells or homologous virus are relatively immune to challenge with live tumour cells (Habel and Eddy, 1963; Potter and Oxford, 1970). The results of transplantation studies with adenovirus 12-induced tumour cells are shown in Table 2; hamsters immunized with irradiated adenovirus 12 tumour cells or soluble extracts from such cells, but not with SV40 tumour cells or adenovirus 12 , were relatively immune to homologous tumour cells challenge.

In addition to TSTA, virus-induced tumour cells contain virus-specific tumour $(T)$ antigen; this antigen is common to all tumour cells induced by a 
single virus, is serologically distinct from $T$ antigens induced by other viruses, and also occurs in cells during lytic infection. The $T$ antigen can be demonstrated in tumour cells using sera from tumourbearing animals in the immunofluorescence test (Pope and Rowe, 1964) or by complement-fixation tests (Black et al., 1963). The results of crosscomplement fixation tests for $\mathrm{T}$ antigen from tumour cells induced by adenovirus 12, SV40 and CELO virus are shown in Table 3.

TABle 3. Titres of complement fixing tumour $(T)$ antigen in virus-induced hamster tumours

\begin{tabular}{lccc}
\hline \multirow{2}{*}{$\begin{array}{l}\text { Serum from hamsters } \\
\text { bearing tumours }\end{array}$} & \multicolumn{3}{c}{$\begin{array}{c}\text { CF titre of antigen extracts of } \\
\text { tumours induced by: }\end{array}$} \\
\cline { 2 - 4 } induced by: & Adenovirus 12 & SV40 & CELO virus \\
\hline Adenovirus 12 & 128 & $<4$ & $<4$ \\
SV40 & $<4$ & 32 & $<4$ \\
CELO virus & $<4$ & $<4$ & 32 \\
Normal serum & $<4$ & $<4$ & $<4$ \\
\hline
\end{tabular}

\section{(b) In vitro transformation}

Many of the DNA viruses capable of inducing tumours in laboratory animals can also transform cells grown in vitro from a normal to a cancerous form (Casto, 1968; Sambrook, 1972); transformed animal cells can be shown to be tumorigenic by inoculating these cells into syngeneic animals and producing tumours (Rabson and Kirschstein, 1962). These techniques provide a method for studying the transformation of human cells; however, these cells cannot be proved to be tumorigenic, but from animal studies the in vitro property which correlates best with tumorigenicity is the loss of contact inhibition. Thus, transformed cells grow in vitro to produce densely packed, multilayered colonies easily recognized by the naked eye; and this provides a measurement of cancerous changes of human cells (Jensen, Koprowski and Ponten, 1963; Todaro and Aaronson, 1968). Human cells can be transformed by SV40 virus (Jensen et al., 1963) but adenovirus 12 transformants are unstable (Todaro and Aaronson, 1968). Cultures derived from human kidney cells, liver or lung are susceptible to transformation by SV40 virus, and the transformation of fibroblasts can be quantitated (Todaro, Green and Swift, 1966). Comparison of the susceptibility of fibroblasts from different patients to transformation by SV40, and the induction of virus-specific $T$ antigen, which parallels this finding (Aaronson, 1970), has shown significant differences. The results obtained using cells from 24 subjects are shown in Table 4. Under standard conditions, approximately one cell in 5000 from normal individuals was transformed following exposure to SV40 virus; the results for cells from patients with Down's syndrome, trisomy $17 / 18$ and Fanconi's anaemia was approximately 3,8 and 7 times greater, respectively. These results, together with those of other similar studies, have shown that cells from patients with Fanconi's anaemia, Down's syndrome and Kleinfelter's syndrome - not evident from the result for a single patient shown in Table 4 are more sensitive to transformation with SV40 virus than normal cells; it is also known that individuals in these groups are more susceptible to natural malignant disease than are normal subjects However, the relationship of cell susceptibility te transformation and the incidence of malignan disease is not simple, since patients with ataxifa telangiectasia or Bloom's syndrome are highly susceptible to cancer, but cells from these patients show no increased susceptibility to virus transformation (Webb and Harding, 1977); other factors, such as DNA repair mechanisms, are involved in both virus transformation and cancer (Setlow, 1978).

\section{(c) DNA virus carcinogenesis}

The intensive studies of tumour induction in experimental animals, and transformation of cells in vitro, has revealed some features of the mechanism

TABLE 4. Transformation of human cell lines by SV40 virus

\begin{tabular}{|c|c|c|c|c|c|}
\hline \multirow{2}{*}{$\begin{array}{l}\text { Chromosome } \\
\text { content }\end{array}$} & \multirow{2}{*}{$\frac{\text { Sex }}{M}$} & \multirow{2}{*}{$\frac{\text { No. listed }}{7}$} & \multirow{2}{*}{$\begin{array}{c}\begin{array}{c}\text { Age range } \\
\text { (years) }\end{array} \\
<1-37\end{array}$} & \multicolumn{2}{|c|}{$\begin{array}{l}\text { Mean transformation } \\
\text { range rate }(-)\end{array}$} \\
\hline & & & & 0.020 & $(0.018-0.030)$ \\
\hline Normal & $\mathbf{F}$ & 5 & $1-35$ & 0.026 & $(0.021-0.028)$ \\
\hline $\begin{array}{l}\text { Down's } \\
\text { syndrome }\end{array}$ & $\left.\begin{array}{l}3 \mathrm{M} \\
3 \mathrm{~F}\end{array}\right\}$ & 6 & $<1-13$ & 0.071 & $(0.061-0.083)$ \\
\hline Trisomy $17 / 18$ & $\mathbf{F}$ & 2 & $<1$ & $0 \cdot 160$ & $(0 \cdot 121-0 \cdot 200)$ \\
\hline XO & $\mathbf{F}$ & 2 & $0-19$ & 0.020 & $(0.019-0.022)$ \\
\hline $\mathbf{X X Y}$ & $\mathbf{M}$ & 1 & 26 & 0.021 & \\
\hline Normal (Fanconi's anaemia) & $\mathbf{M}$ & 1 & 2 & $0 \cdot 152$ & \\
\hline
\end{tabular}


of DNA virus carcinogenesis; however, this process is far from fully understood. Studies with SV40 and adenoviruses have shown that the agent of viral transformation is DNA, since purified viral DNA can transform cells in vitro (Aaronson, 1970). Moreover, only a portion of the DNA is necessary; thus transformation of cells by adenovirus types 2 or 5 or SV40 requires only a small fragment of the virus nucleic acid (Sambrook et al., 1968; Ginsberg et al., 1974). Consequences of infection by transforming virus are increased cell DNA synthesis, chromosome breakage and subsequent repair with integration of the transforming piece of viral DNA into host cell DNA (Sambrook et al., 1968). Since only a portion of virus DNA persists in transformed cells, the cells do not usually contain infective virus but small quantities of infective virus can be recovered from some strains of SV40 virus transformed cells. The identification of a specific fraction of virus DNA required for transformation indicates that the alteration in cell behaviour is triggered by a specific gene or gene product(s) (Green, 1977); only early RNA sequences of virus replication are transcribed in tumour cells, and the gene products are limited. The size of the virus-specific RNA in adenovirustransformed cells has been determined, and this is comparable with the translation of a protein of molecular weight of 70000 (Green, 1977). This protein has been identified as the ' $T$ ' antigen which has a molecular weight of approximately 70000 and binds to DNA. The ' $T$ ' antigen of transformed cells is different from the antigen form found in productively infected cells (Carroll and Smith, 1976) and, from genetic studies, the protein has been shown to be essential to the transformation process (Butel, Brugge and Noonan, 1974).

Although much of the molecular events which result in cell transformation by viruses are unknown, certain features of virus-induced tumours suggest approaches for the study of human tumours. Thus, tumours induced by adenoviruses or SV40 contain virus-specific DNA and RNA, contain ' $T$ ' antigen and induce virus-specific $T$ antibody and virusspecific transplantation immunity. These features have been looked for in cancer patients without success (Green, 1977), and within the limits of available technology these viruses do not seem to have a biological role in normal cancers of man. It remains to be seen whether specific products of other viruses can be found in human cancer cells.

\section{Viruses and cancer of the cervix}

Although evidence of a role for adenoviruses and SV40 virus in human cancer has not been found, the principles determined and the techniques designed in the study of these agents can be used for the study of other viruses in malignant disease. From these studies, EB virus of infectious mononucleosis is probably implicated in Burkitt's lymphoma and nasopharyngeal carcinoma (Zur Hausen, 1975), and evidence for this and other viruses in human leukaemia, Hodgkin's disease and other malignant diseases has been sought (Rapp and Reed, 1977). Herpesvirus type 2 (HSV-2) is thought by some workers to be an aetiological agent of carcinoma of the cervix, and the search for evidence to establish this association is being intensively pursued by a number of researchers, and will now be summarized.

\section{Laboratory studies}

(a) Transformation by herpesvirus type 2 (HSV-2). The proved oncogenic properties of members of the herpesvirus group in animals (Rapp and Westmoreland, 1976) has long given rise to speculation of the possible role of these viruses in cancer in man. This possibility received fresh interest when HSV-2 was shown capable of transforming cells in vitro (Duff and Rapp, 1971). Herpesvirus-2 causes a lytic infection of human and numerous animal cells; however, treatments to the virus which limit the cell destructive effects can result in virus infection producing cell transformation. The summary of several studies with HSV-2 are given in Table 5, together with those of studies with HSV-1. By u.v.-treatment of virus before infection, or by incubating virus-infected cells at temperatures which limit virus replication, HSV-2 can be shown to transform mouse, rat and hamster cells in vitro. In each case transformation was indicated by alteration in cell growth and morphology, and by tumour production in animals. Human cells have also been transformed by HSV-2; the criteria of transformation in this case were alteration of cell growth and morphology, prolonged cell growth in vitro and the presence of virus-specific antigen, but not infective virus (Darai and Munk, 1973).

Herpesvirus- 2 infection of laboratory animals is a cytolytic infection which commonly results in death. However, intravaginal infection of mice with u.v.irradiated virus, or infection of animals previously immunized with inactivated virus can then produce cytological changes of dysplasia and invasive cancer (Munoz, 1973; Wentz et al., 1975).

(b) Properties of HSV-2 transformed cells. Cells transformed by HSV-2 have similar growth properties to cells transformed by other DNA viruses (Rapp and Westmoreland, 1976), and do not contain infective virus (Skinner, 1976; Duff, Doller and Rapp, 1973). Analysis of transformed cell DNA has shown the presence $3-32 \%$ of the HSV-2 genome present in 1-5 copies (Frankel et al., 1976), and this is consistent with the finding that transformation of mouse cells can be accomplished with a fraction of HSV-2 DNA (Maitland and McDougall, 1977). 
TABLE 5. Transformation of cells in vitro with herpesvirus hominis type 2

\begin{tabular}{|c|c|c|c|c|c|}
\hline \multirow[b]{2}{*}{ Treatment } & \multirow[b]{2}{*}{$\begin{array}{c}\text { Cells } \\
\text { transformed }\end{array}$} & \multicolumn{4}{|c|}{ Criteria of transformation } \\
\hline & & $\begin{array}{c}\text { Cell } \\
\text { morphology } \\
\text { and growth }\end{array}$ & $\begin{array}{l}\text { Virus-specific } \\
\text { antigens }\end{array}$ & $\begin{array}{l}\text { Cell growth } \\
\text { in soft agar }\end{array}$ & $\begin{array}{l}\text { Tumours in } \\
\text { animals }\end{array}$ \\
\hline Ultra-violet irradiation & $\begin{array}{l}\text { Mouse } \\
\text { Rat } \\
\text { Hamster }\end{array}$ & $\begin{array}{l}+ \\
+ \\
+\end{array}$ & $\begin{array}{l}+ \\
+ \\
\pm\end{array}$ & $\begin{array}{c}- \\
\text { n.t. } \\
+\end{array}$ & $\begin{array}{l}+ \\
+ \\
+\end{array}$ \\
\hline Growth at $20^{\circ} \mathrm{C}$ & Rat & + & n.t. & + & + \\
\hline Growth at $40^{\circ} \mathrm{C}$ & Hamster & + & \pm & + & + \\
\hline Growth at $42^{\circ} \mathrm{C}$ & $\begin{array}{l}\text { Rat } \\
\text { Human }\end{array}$ & $\begin{array}{l}+ \\
+\end{array}$ & $\begin{array}{c}\text { n.t. } \\
+\end{array}$ & $\begin{array}{l}+ \\
\text { n.t. }\end{array}$ & $\begin{array}{c}+ \\
\text { n.t. }\end{array}$ \\
\hline
\end{tabular}

n.t. $=$ not tested $\pm=$ conflicting results.

Various studies have detected virus-specific proteins in HSV-2 transformed cells using immunofluorescence or complement fixation (Rapp and Westmoreland, 1976); in contrast to the viral antigens in cells transformed by other DNA viruses, HSV-2 specific antigens are located in the cytoplasm, show weak staining and are only visible in a proportion of the cells. Skinner (1976) detected virus-specific antigen in the early passages of transformed hamster cells, but the cells were negative for both virus DNA and antigens at later passage levels; however, other studies have reported the presence of virus-specific proteins in transformed cells after prolonged culture (Gupta and Rapp, 1977).

Cells transformed in vitro by HSV-2 frequently produce tumours when inoculated into syngeneic animals; the tumours from the most oncogenic of transformed cells grow rapidly, are encapsulated with much central necrosis and metastasize to the lung and later to other organs (Fig. 1). The histogenesis of the tumour is variable, depending probably on the nature of the original transformed cell, but are most commonly described as fibrosarcomas (Boyd, 1975). The tumours induce a number of host responses. Thus, immunization with $\mathrm{X}$-irradiated tumour cells or fetal hamster cells induce immunity to transplanted tumour cells, indicating the presence of both transplantation and fetal antigen on the tumour cells, but immunization with HSV did not induce immunity (Duff et al., 1973): this later finding is quite distinct from the behaviour of SV40 or adenovirus-induced tumours. Serum from tumour-bearing hamsters has been reported to contain HSV neutralizing antibody (Rapp and Westmoreland, 1976); however, no antibody was found in sera from hamsters inoculated with cloned cell lines (Boyd, 1975; Skinner, 1976).

\section{Human studies}

(a) Epidemiology. Extensive epidemiological studies have indicated the association of promiscuity with carcinoma of the cervix, and have observed the importance of age of first coitus and the number of sexual partners in the incidence of this cancer (Kessler, 1976). In addition, the incidence is relatively high among women whose husbands have penile cancer (Martinez, 1969), among prostitutes and in association with venereal diseases (Rojel, 1953) and in the wives of men whose first wives died of carcinoma of the cervix (Kessler, 1976) These findings have been interpreted as signifying $\overrightarrow{0}$ that carcinoma of the cervix is caused by a venereally transmitted factor; indeed, the evidence is held to point to the existence of high-risk males who are most likely to transmit the agent of the disease (Singer, Reid and Coppleson, 1975; Kessler, 1976). The nature of the transmitted agent is not known; from experiments of cell transformation the most probable agent would be nucleic acid, either as viral or sperm DNA (Rapp and Westmoreland, 1976; Singer and Stevenson, 1972). In addition to the above epidemiological findings there is evidence for the existence of high-risk females. The production of $\alpha_{1}$-antitrypsin is genetically controlled by $\mathrm{Pi}$ alleles, and subjects possessing the $\mathrm{Pi}^{\mathrm{s}}$ or $\mathrm{Pi}^{\mathrm{z}}$ phenotypes produce low levels of this serum protein and number only $8 \%$ of the population; in contrast, these phenotypes occur with significantly higher frequency in patients with carcinoma of the cervix (A. Singer and A. M. Ward, personal communication).

(b) Virus isolation. Herpesvirus infection is common in man, and serological evidence of past infection can be demonstrated in over $90 \%$ of adults; however, the majority of infections are by HSV-1, and antibody to HSV-2 is demonstrable in only 15$25 \%$ of normal adults (Skinner, Whitney and Hartley, 1977; Christensen and Epsmark, 1976). Herpesvirus- 2 is an increasingly common venereal infection; the virus can be isolated from the vesicular 

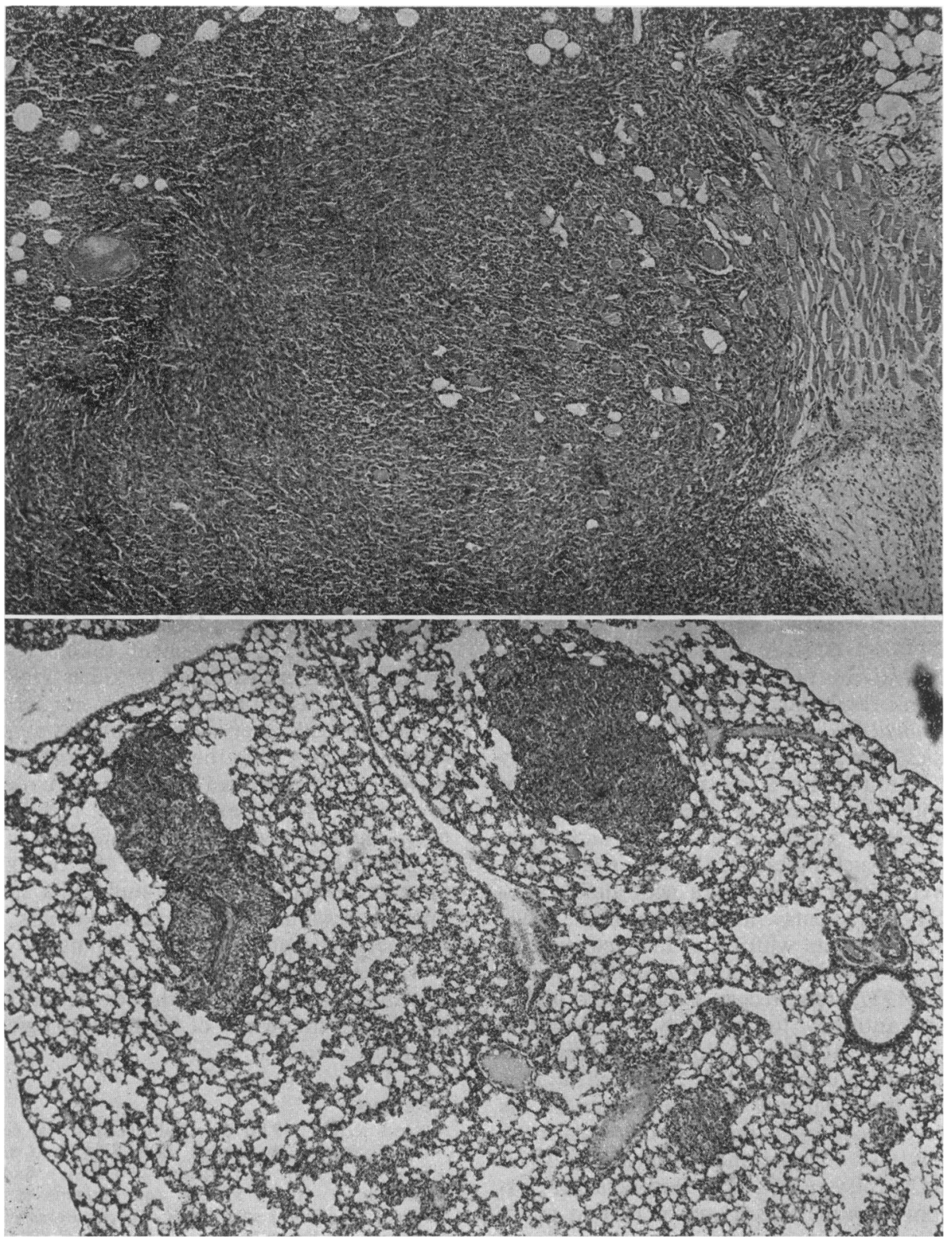

FIG. 1. Tumours induced by herpes simplex virus -2 transformed cells. HSV-2 transformed cells forming a primary subcutaneous fibrosarcoma (top). Multiple metastases in lung (bottom).

lesions, but not from the same areas during remission, and occasionally from the sacral ganglia of cadavers. Evidence of an increasingly high incidence of HSV-2 infection in patients attending special clinics has been obtained in many studies (Rawls, Adam and Melnick, 1973). In addition, HSV-2 was isolated from the genital tract of $1.6 \%$ of asymptomatic women and $8-29 \%$ of similar men; the reason for this sex difference is not known (Centifanto, Drylie and Deardourff, 1972; Kleger et al., 1968).

Investigation of HSV-2 infection in patients with dysplasia and carcinoma of the cervix has revealed histological evidence of HSV infection in $23.7 \%$ of biopsy specimens. HSV-2 has been recovered from cervical cancer cells grown in tissue culture at 
a relatively high pH (Aurelian, 1973). From laboratory studies of HSV-2 and other DNA virus transformed cells outlined above, the recovery of infective HSV-2 virus from carcinoma cells argues against this virus as a cause of the malignancy. In addition, since cells transformed in vitro by HSV-2 show increased resistance to $\mathrm{HSV}-2$ infection (Darai and Munk, 1973), the presence of virus in carcinoma cells argues against this viral aetiology for this cancer.

Papovavirus and adenovirus-induced tumour cells contain variable amounts of viral DNA, even in the absence of infective virus, and similar results have been found for HSV-2 transformed hamster cells (Frankel et al., 1976). Thus, the identification of a fragment of HSV-2 DNA in cells from a human cervical tumour was highly provocative (Frankel $e t$ al., 1972); however, this finding has not been confirmed. In studies of hamster cells transformed by HSV-2, Skinner (1976) was unable to demonstrate HSV-2 DNA in cloned cell populations; the author suggested that after virus transformation the cells could lose viral DNA nucleic but retain other properties of transformation. This could explain the absence of HSV-2 DNA in carcinoma of the cervix cells should this virus be the agent of transformation but, again, this result has not been confirmed.

(c) Serological studies. The results of a large number of studies have shown that neutralizing antibody to HSV-2 is found more frequently in sera from patients with carcinoma of the cervix than in controls; however, studies in Colombia and Japan have shown no such difference (Rawls et al., 1973). The relatively higher incidence of neutralizing antibody to HSV-2 in patients with carcinoma of the cervix is not seen in patients with other malignancies. In addition to neutralizing antibody, Aurelian, Strnad and Smith (1977) reported a significantly higher incidence of antibody to the early, virus-specific structural protein AG-4, and Notter and Docherty (1976) to an early product of HSV-2 infected hamster cells in sera from patients with carcinoma of the cervix than in controls; the antibody has been suggested as IgG (Falaky and Vestergaard, 1977) and non-IgG (Thiry et al., 1977). Despite some conflicting reports, most authors agree that in many countries there is a significantly increased incidence of HSV-2 antibody in patients with carcinoma of the cervix. This should not be surprising since carcinoma of the cervix is associated with promiscuity and venereal infection, and HSV-2 causes venereal disease; the high incidence of HSV-2 antibody in patients with carcinoma of the cervix can be argued as concomitant factors which are not necessarily connected.

(d) Conclusions. The present evidence of HSV-2 infection, either by virus isolation or serological studies in patients with carcinoma of the cervix, does not contribute significantly to the theory that this virus is an aetiological agent of this malignancy, since detractors will point out that the 2 conditions are associated by the common factor of promiscuity. On the other hand, the epidemiology of carcinoma of the cervix, the oncogenic potential of herpesvirus in other species, the probable association of the EBV with Burkitt's lymphoma, and the ability of HSV-2 to transform human cells in vitro and produce carcinoma of the cervix in animals draws attention to the possible role of this virus in cervical cancer. To further our present knowledge one of the most important needs is for a better understanding of HSV-2 transformation. The conditions under which this occurs in the laboratory are highly artificial, and studies aimed at determining if transformation can occur under more natural and physiological conditions are needed. Since the method of transformation could determine the properties of the transformed cell, it is possible that the artificially induced HSV-2 transformed cells at present being studied are not relevant. Secondly, the persistence of virus DNA and antigens in HSV-2 cells may not be permanent (Skinner, 1976), as found in cells transformed by other DNA viruses; thus, virus-specific products may not be detectable in human cells even when HSV-2 was the transforming factor. For this reason, long-term studies of HSV-2 transformed cells are required. Finally, a variety of single serological techniques have been used to assess HSV-2 infection in a group of patients with carcinoma of the cervix; perhaps more revealing would be a study of a spectrum of immune responses in the same patients, including cell-mediated and humoral immune responses. It is too early to conclude on the relevance of HSV-2 infection to carcinoma of the cervix, and judgement must await the results of further virological investigations.

\section{References}

Aaronson, S.A. (1970) Susceptibility of human cell strains to transformation by simian virus SV40 and simian virus deoxyribonucleic acid. Journal of Virology, 6, 470.

AURELIAN, L. (1973) Virions and antigens of herpesvirus type 2 in cervical carcinoma. Cancer Research, 33, 1539. Aurelian, L., Strnad, B.C. \& Smith, M.F. (1977) Immunodiagnostic potential of a virus-coded tumor-associated antigen (AG-4) in cervical cancer. Cancer, 39, 1834.

BlaCk, P.H., Rowe, W.P., Turner, H.C. \& Huebner, R.J. (1963) A specific complement-fixing antigen present in SV40 tumor and transformed cells. Proceedings of the National Academy of Sciences of the United States of America, 50, 1148.

BoyD, A.L. (1975) Characterization of single-cell clonal lines derived from HSV-2-transformed mouse cells. Intervirology, 6, 156.

Butel, J.S., BRugge, J.C. \& Noonan, C.A. (1974) Transformation of primate and rodent cells by temperaturesensitive mutants of SV40. Cold Spring Harbor Symposium on Quantitative Biology, 39, 25. 
Carroll, R.B. \& Smith, A.G. (1976) Monomer molecular weight of $T$ antigen from simian virus 40 - infected and transformed cells. Proceedings of the National Academy of Sciences of the United States of America, 73, 2254.

CAsto, B.C. (1968) Adenovirus transformation of hamster embryo cells. Journal of Virology, 2, 376.

Centifanto, Y.M., Dryle, D.M. \& Deardourff, S.L. (1972) Herpesvirus type 2 in the male genitourinary tract. Science. New York, etc., 178, 318.

Christensen, B. \& Epsmark, A. (1976) Long-term follow-up studies on herpes simplex antibodies in the course of cervical cancer. Il. Antibodies to surface antigen of herpes simplex virus infected cells. International Journal of Cancer, 17, 318.

Churchill; A.E. \& Briggs, P.M. (1967) Agent of Marek's diśease in tissue culture. Nature. London, 215, 528.

DaraI, G. \& Munk, K. (1973) Human embryonic lung cells abortively infected with herpesvirus hominis type 2 show some properties of cell transformation. Nature. London, 241, 268.

Duff, R., Doller, E. \& Rapp, F. (1973) Immunologic manipulation of metastasis due to herpesvirus transformed cells. Science. New York, etc., 180, 79.

DUFF, R. \& RAPP, F. (1971) Oncogenic transformation of hamster cells after exposure to herpes simplex virus type 2. Nature. London, 233, 48.

Ellerman, V. \& BaNG, O. (1908) Experimentelle leukämie bei hühnern. (Abstract) Zentralblatt für Bakteriologie, Parasitenkunde, Infektionskrankheiten und Hygiene, 46, 595.

FALAKY, I.H. \& VestergaARD, B.F. (1977) IgG-, IgA and IgM-antibodies to herpes simplex virus type 2 in sera from patients with cancer of the uterine cervix. European Journal of Cancer, 13, 247.

Frankel, N., Locker, H., Cox, B., Roizman, B. \& RapP, F. (1976) Herpes simplex virus DNA in transformed cells: sequence complexity in five hamster cell lines and derived hamster tumour. Journal of Virology, 18, 885.

Frankel, N., Roizman, B., Cassai, E. \& Nahmias, A. (1972) A DNA fragment of herpes simplex 2 and its transcription in human cervical cancer tissue. Proceedings of the National Academy of Sciences of the United States of America, 69, 3784.

Ginsberg, H.S., Ensinger, M.J., Kauffman, R.S., Mayer, A.J. \& LUNDhOLM, U. (1974). Cell transformation: a study of regulation with type 5 and 12 adenovirus temperature-sensitive mutants. Cold Spring Harbor Symposium on Quantitative Biology, 39, 419.

GREEN, M. (1977) DNA and RNA tumor viruses - molecular events of virus replication and cell transformation and role in human cancer. Advances in Pathobiology, 42, 33.

GUPTA, P. \& RAPP, F. (1977) Identification of virion polypeptides in hamster cells transformed by herpes virus type 1. Proceedings of the National Academy of Sciences of the United States of America, 74, 372.

HABEL, K. \& EdDY, B.E. (1963) Specificity of resistance to tumour challenge of polyoma and SV40 virus-immune hamsters. Proceedings of the Society for Experimental Biology and Medicine, 113, 1.

Jensen, F., Koprowski, H. \& Ponten, J.A. (1963) Rapid transformation of human fibroblast cultures by simian virus 40. Proceedings of the National Academy of Sciences of the United States of America, 50, 343.

KESSLER, I.I. (1976) Human cervical cancer as a venereal disease. Cancer Research, 36, 783.

Kleger, B., Prier, J., Rosato, D. \& McGinnis, A.E. (1968) Herpes simplex infection of the female genital tract. American Journal of Obstetrics and Gynecology, 102, 745.

KLeIN, G. (1972) Herpesviruses and oncogenesis. Proceedings of the National Academy of Sciences of the United States of America, 69, 1056.
LUCKE, B. (1938) Carcinoma in the leopard frog: its probable causation by a virus. Journal of Experimental Medicine, 68, 457.

MARTINEZ, I. (1969) Relationship of squamous cell carcinoma of the cervix uteri to squamous cell carcinoma of the penis among Puerto Rican women married to men with penile carcinoma. Cancer, 24, 777.

Maitland, N.J. \& McDougall, J.K. (1977) Biochemical transformation of mouse cells by fragments of herpes simplex virus DNA. Cell, 11, 233.

Merkov, L.P. \& SLIFKIN, M. (1973) Simian adenoviruses. Progress in Experimental Tumor Research, 18, 67.

MUNOZ, N. (1973) Effect of herpesvirus type 2 and hormonal imbalance in the uterine cervix of the mouse. Cancer Research, 33, 1504.

Nahmias, A.J., Josey, W.E., Niab, Z.M., LuCE, C.F. \& DufFy, A. (1970) Antibodies to herpesvirus hominis types 1 and 2 in humans. American Journal of Epidemiology, $91,539$.

NOTTER, M.F.D. \& DocherTY, J.J. (1976) Reactions of antigens isolated from herpes simplex virus-transformed cells with sera of squamous cell carcinoma patients. Cancer Research, 36, 4394.

POPE, J.H. \& RowE, W.P. (1964) Detection of specific antigen in SV40-transformed cells by immunofluorescence. Journal of Experimental Medicine, 120, 121.

POTTER, C.W. \& OXFORD, J.S. (1970) Transplantation immunity following immunization with extracts of adenovirus 12 tumour cells. International Journal of Cancer, 6, 410.

RABSON, A.S. \& KIRSCHSTEIN, R.L. (1962) Induction of malignancy in vitro in newborn hamsters kidney tissue infected with simian vacuolating virus (SV40). Proceedings of the Society for Experimental Biology and Medicine, 111, 323.

RAPP, F. \& REED, C.L. (1977) The viral etiology of cancer. Cancer, 40, 419.

RAPP, F. \& WeStMoreland, D. (1976) Cell transformation by DNA-containing viruses. Biochimica et biophysica acta 458, 167.

Rawls, W.E., Adam, E. \& Melnick, J.L. (1973) An analysis of seroepidemiological studies of herpesvirus type 2 and carcinoma of the cervix. Cancer Research, 33, 1477.

RoJel, J. (1953) The interrelation between uterine cancer and syphilis: a pathodermographic study. Acta pathologica et microbiologica scandinavica (Sect. A), 97, 13.

SAMBRooK, J. (1972) Transformation by polyoma virus and simian virus 40. Advances in Cancer Research, 16, 141.

Sambrook, J., WestPhal, H., Srinivasan, P.R. \& Dulbecco, R. (1968) The integrated state of viral DNA in SV40transformed cells. Proceedings of the National Academy of Sciences of the United States of America, 60, 1288.

SETLOW, R.B. (1978) Repair deficient human disorders and cancer. Nature. London, 271, 713.

Singer, A., Reid, B. \& Coppleson, M. (1975) The role of a high-risk male in the etiology of cervical carcinoma - a correlation of epidemiology and molecular biology. American Journal of Obstetrics and Gynecology, 126, 110.

Singer, A. \& Stevenson, M. (1972) Carcinoma of the cervix and herpesvirus. British Medical Journal, 2, 290.

SkINNER, G.R.B. (1976) Transformation of primary hamster embryo fibroblasts by type 2 simplex virus: evidence for a "hit and run" mechanism. British Journal of Experimental Pathology, 57, 361.

Skinner, G.R.S., Whitney, J.E. \& Hartley, C. (1977) Prevalence of type-specific antibody against type 1 and type 2 herpes simplex virus in women with abnormal cervical cytology. Archives of Virology, 54, 211.

Thiry, L., SPrecher-Goldberger, S., HANNeCART-POKORNI, E., Gould, I. \& Bossens, M. (1977) Specific non-immunoglobulin $G$ antibodies and cell-mediated response to 
herpes simplex virus antigen in women with cervical carcinoma. Cancer Research, 37, 1301.

Todaro, G.J. \& Aaronson, S.A. (1968) Human cell strains susceptible to focus formation by human adenovirus type 12. Proceedings of the National Academy of Sciences of the United States of America, 61, 1272.

Todaro, G.J., Green, H. \& SwifT, M.R. (1966) Susceptibility of human diploid fibroblast strains to transformation by SV40. Science. New York, etc., 153, 1252.

TodARo, G.J. \& HuebNer, R.J. (1972) The viral oncogene hypothesis: new evidence. Proceedings of the National Academy of Sciences of the United States of America, 69, 1009.
Trentin, J.J., Van Hoosier, G.L. \& Samper, L. (1968). The oncogenicity of human adenoviruses in hamsters. Proceedings of the Society for Experimental Biology and Medicine, 127, 683.

WebB, T. \& HARding, M. (1977) Chromosome complement and SV40 transformation of cells from patients susceptible to malignant disease. British Journal of Cancer, 36, 583.

Wentz, W.B., Facog, J.W., Reagan, J.W. \& Heggie, A.D. (1975) Cervical carcinogenesis with herpes simplex virus type 2. American Journal of Obstetrics and Gynecology, 46, 117.

Zur HAuSEN, H. (1975) Oncogenic herpes viruses. Biochimica et biophysica acta, 417, 25. 